\title{
CNOT3 wt Allele
}

National Cancer Institute

\section{Source}

National Cancer Institute. CNOT3 wt Allele. NCI Thesaurus. Code C107659.

Human CNOT 3 wild-type allele is located in the vicinity of 19q13.4 and is approximately $18 \mathrm{~kb}$ in length. This allele, which encodes CCR4-NOT transcription complex subunit 3 protein, plays a role in RNA processing, translational regulation and transcriptional regulation. 